\title{
English Language and its Importance of Learning it in Albanian Schools
}

\section{PhD Ervin Balla}

\author{
University Aleksander Moisiu,
} Durres Albania

Doi: 10.2478/ajis-2018-0035

\begin{abstract}
Taking into consideration many factors that indicate that the English language has taken an important place in communication and its use by millions in the whole world has become a necessity and not an unecessary subject in the teaching process in Albanian universities. As a result of that many countries including Albania are seeing an increase of the demand for teaching the English language since the first grades. Also it is found necessary the addition of classes of foreign languages in Albanian schools and universities. The curricula of the language is enriched each year and the new methods are becoming more profitable in teaching the language. Naturally teaching the English at school is becoming important not only academically but also in the practical aspect of learning, such as using language for various purposes such as business purposes, communication, reading foreign books especially in literature or other types. In the aspect of learning the language in the school not only the book is important but also other factors need to be taken into account.
\end{abstract}

Keywords: English language, teaching, learning English curricula, Universities, learning

\section{English at School}

Taking into consideration the factors that are mentioned and also other factors that indicate that the English language has taken an important place in communication and its use by millions of people all around the world, the teaching of which has become a necessity and not a second hand subject in the process of teaching in Albanian universities. Due to that many countries and involving the Albania too are facing an increase of the demand for teaching English since the first grades. Seeing the importance of learning English and other foreign languages inAlbania is seen as a necesity the increase of classes in Albanian schools and universitites. The curricula of the foreign language is enriched each year and new methods have become more fruitful in teaching it also the testing of the language in state exams has played an imprortant role in teaching learning process by the students. According to Broughton it's no surprise seeing the great importance of English in all the world have been given more classes than any other subject developed in universities.

Naturally the subject of English in Albanian schools is becoming of a special importance not only in academic aspect but also in the practical aspect of the language as lingua franca in businesses, different works or daily comunnications. In the teaching aspect of the language at schools not only the books used for learning the language plays its role but also other factors are important too. According to Murcia to have good results in his work, the English teacher have to keep in mind certain factors.

First the teacher has to assess the need of the students to learn the English language. Why would they like to learn English? Secondly teacher has to assess some other factors in learning such as the frequency in learning, so how many times a week is the Englich course held? The size of the classroom and the number of the students in the class, the quality of the materals used (text 
books, syllabuses). Based in all of these thinges mentioned above the teacher may decide what to teach and what prorities can be taken into consideration.

Study of English language or other foreign languages in Albanian schools start early, since fifth grade or in some schools in third or forth grade or even earlier, but the early study of this language in Albanian schools does not correspond to the study of English language in other countries of European Union when the study of this language starts at the age of three in preelementary education, and according to this declaration the English language is the foreign most learnt language in those countries. Nevertheless the knowledge gained in the elementary classes are modest, students find it necessary to gain the knowledge of this language, to create their normal behaviour in the study of the language, where the traditional teaching with the teacher at the center of the method is developed normally in most of the schools of the cities and villages. In Albania like in many other cuntries that study English the level of knowledge of students in classes is homogenous, in which students may vary from beginers to advanced level.

If the teachers of foreign languages in Albania would teach a rare language such as Chinese language or Swomi language, very few or none of the students would own it, an we would start from very begining for all the students and using the same method for every one which is not the same case for English language.

According to Harmer English classes of various levels have their problems and the teacher has always the responsbility to give an apropriate solution, startng to the work groups, use of methods according to the level of knowledge and with topics in accordance to their level and age, and of course to work in regard of motivation and stimulation to reach high results. Also acording to Brughton a continous attempt in regard of learning the language is much more efective than a spontaneous learning of language. The type of continous exposure of students with the foreign language and the daily communication with them makes possible the accomplishment of purposes with the students of various levels of English knowledge.

From the learning point of view "the more someone is exposed to a foreign language the more he learns" but learning the modern languages in schools has also an educational purpose, and the student who decides to study English has clearly an instrumental purpose, he may want to visit England or other plases where English is the first language, he would like to communicate with his English speaking friends, study abroad, or even find a better job, or get promoted.

Table 1: Purpose of learning English

\begin{tabular}{|c|c|c|c|c|c|}
\hline Questions & & Altern & atives & & \\
\hline & $\begin{array}{l}\text { 1. Not } \\
\text { agree }\end{array}$ & $\begin{array}{l}\text { 2. Partly } \\
\text { agree }\end{array}$ & $\begin{array}{c}3 . \\
\text { Neutral } \\
\end{array}$ & $\begin{array}{c}4 . \\
\text { Agree }\end{array}$ & $\begin{array}{l}5 \text { Totally } \\
\text { agree }\end{array}$ \\
\hline 1 I would like to get a better mark that's why I learn it & 6 & 20 & 18 & 37 & 18 \\
\hline 2 Would like to study English because I would like to study abroad & 16 & 24 & 12 & 27 & 20 \\
\hline 3 I would like to study English because I would like to find a job & 2 & 4 & - & 27 & 67 \\
\hline $\begin{array}{l}4 \text { I would like to study English because I would like to study } \\
\text { foreign literature in English literature }\end{array}$ & 8 & 10 & 12 & 43 & 27 \\
\hline $\begin{array}{l}5 \text { I would like to learn English because I think it is a beautiful } \\
\text { language }\end{array}$ & - & 8 & 8 & 33 & 51 \\
\hline
\end{tabular}

About 50 students of the Informatics branch of the university "Aleksander Moisiu" Durres, answered the questions of a questionaire, that why they study English language. The answers were stored below and the charts to understand the true reasons why the majority of students study the English language

\section{Conclusions of Questionaire}

As it was seen from the questionaire a considerable number of students $37 \%$ have admited that they study the language for a better mark and also a considerable number of students would like to study English because they would like to follow their studies abroad, nevertheless this was not as 
high as the first question, which is taking a good grade. Meanwhile it can be seen that a high number of students who hopped to find a job where English is used was $68 \%$. Also reading masterpieces in English the motivation to learn the English language was high. It was 43\%, but surprisingly the number of students who wanted to learn English because they considered it beautiful (even though considering the language beautiful is a little bit personal because in the questionaire were not mentioned the elements that make a language beautiful) was $53 \%$.

\section{English Curricula}

According to Brown J.D traditionally, the developers of curriculas have supposed that (a) students need to learn English of the native speakers of English (b) educated native speakers must serve as a standard and as a model (c) should be taught the American or British culture (d) communicative teaching is the most productive way to learn English. Curricula developers also have supposed that students learn English because English is the key tool for global communication (b) English helps develop internationalism (c) English is important to continue studies for the higher education (d) English is the first language for global information. The control for designing curriculas has always been in the hands of native speakers of English, whom either have written the text books or have led the development of local curriculas by placing in doubt the valuability of pedagogic model based in the principles of competences of communication. With the standardised norm of the local speakers the model seems utopic, nonrealistic and obstacle in relationships of English as an international language.

Cultural content. Traditionally the British and American cultures have served as target culture of the curriculas of English language, however what the authors imply with culture very frequently is not very clear. Culture may mean with "C" that involves literature, art, music etc, or may mean calendar culture that deals with history, geography and politics etc, or with "c" focused to behaviour and social knowledge that people use to interpret the experience. While McKay argues that assumptions about the teaching and learning of the language of the local community have to be taken into account in the formation of the target culture especially for the things that have to do with the options of the target language, target culture and pedagogy culture. No doubt that many students would like to learn the English as native speakers for various purposes such as study abroad, emigration in the English speaking countries, but the majority of the people use the language for local purposes, or simply to meet the acquisition of the language at schools or at work.

\subsection{What and who is involved in the curricula?}

As it was mentionet above traditionally the native speakers of the foreign language have always controlled the curricula of the foreign language by writing the text books. According to Brown in the today's world it is made clear that at least the following groups have an influence in each curricula and for this reason they should be involved in the process of curricula development at least as sources of information.

1. Students

2. English teachers

3. Curricula developers

4. Texts writers

5. Course teachers

6. Business Communities

7. Institutions adminstrators

8. Outer testers and institutions of testings

9. Other influences people etc.

Distinctions in those groups may prove that they are problematic in the designing of curricula, involving distinctions in (a) English that they use or percept, (b) their point of view that what may contain the learning of the sounds and education, (c) whom they think should teach (d) how they think the English shuld be tought etc.

Llurda stresses that the latest joint research on the English as an international language 
together with the assessment of the growing number of non native speakers of English are creating the appropriate conditions for the gradual admission of English as Lingua Franca and consequence of reducing the role of the local teachers in placing the norms and principles on which Lingua Franca will be learned in the future. Lin suggests to use the discourse to take decissions on what should be involved in sullabuses, argumenting that "Discurse is the level of the language that allows the mutual understanding in communcation with the distinction between the varieties in phomological, lexical, and sintaxtic levels, discurse according to her is to reach the scope with the language. According to Brown usually the choice that which structures, situatins, topics need to be learned based in rationale such as use, importance etc.

Teaching English language in Albanian universities may not be complete without the teaching of Englsh for specific purposes (ESP). Socio- linguistic researches have made teachers of English more aware for the functions of the language clarifying in this regard the purposes of teaching. The idea that many students of English need the language for instrumental purposes has led in teaching English for specific purposes."Show me what you need the English and I will show you what type of English you need" became the moto of English for specific purposes (ESP).

This thing led to the creation of courses and creation of specific methds for teaching English language in varius branches of science, engeneering, medicine, agriculture, economy, tourism etc. Naturally to learn English for specific purposes to the students is something very good for the globalized market of work.

Also new developments in educational psychology led in the increase of the number of the students that studied English for specific purposes, stressing the special importance of the students and their behaviour in learning.

The increase of students that learn English for specific purposes happened due to various factors such as, increase of demand for English language and to adopt to the special needs and developments in the language field and educational psychology.

The assumption for this method was that adjusting English with their needs would improve the motivation of the students making learning faster and better. At the same time since the demand to learn English in compliance with the needs of the students, became a necessity of the time and due to that, new ideas flowrished for the study of the language. Traditionally the purpose of the linguistics was the description of the rules to use English, but the traditional learning of English pointed out the learning of gramar, but new studies changed the focus of language for true purposes. A discovery of this study was that the language that we use changes from one context to another one. The assumption for this method that was adjusting English with their needs would improve the motivation of the students making the acquisition of the language faster and better.

So the focus to the learning English for specific purposes at universities and schools make students to gain professional knwledge of the branch in which they study, which normally has its flaws. If the learning is focused only to the specific purposes English and is not combined with the general purpose English it will result in a mechanical learning of some expressions will not help the future specialists a normal communication in every day expressions in English. For i.e. an engeenier that learns English language only for specific purposes is limited in the use of that language in other fields and it would be difficult for him to express simple demands such as invitations to his friends to visit his country etc. As matter of fact the more specialised becomes the learning of English the more it resembles to training and becomes less part of the process of acquisition. The importance of English for specific purposes is increasing and naturally there are many factors behind such as:

1. Increase of learning the professions and different trainings in all the world has made the education less academic and more practical, students would like to adress their studies to something more valuable. Into knowledge that may be useful when they will start their work

2. Globalization continues to spread and globalization has chosen English as its own language. English is spreading rapidly, there are not only politicians, business leaders and academic professors that need to talk to their international colleagues, but there are also receptionists of hotels, phone call operators, construction workers that move within the EU that need to talk English language. 
3. At the same time general English is taught in the whole world in earlier stages and with a great success. At this point students will finish sucessfully learning English and will not like to repeat the same things after their studies at universities and after the university markets and business trades would like to hire professionals.

\section{English as a Business Language}

English language comes to aid in varius transactions in the whole world. The researches indicate that the communication of the business in the world and in various countries is made in English. English is overruling the business and has become almost a necessity for people to talk in English if they want to join the working forces. From what is said above natyrally raises the question: what has made this language so necessary? The English language went so far that at the twenty century it could be considered in such terms such as: "Global English" or "English as an international language" or more involving "Global English". According to Northrup one of the main reasons for this thing is because Englsh has become the Lingua Franca of the business today in the world.

Some interesting examples come from Finland. Starting from 1990 Kone a well-known for the production of elevators extended its activity in Sweden, Austria and Germany. Kone started to write its financial reports in English. This practice became official policy for its high official that they have to become fluent in English. The other well-known company in the production of mobile phones Nokia also uses English for its communication inside the company. Also the Siemens uses English as the corporation language in 1998. In 2011 Deutche Bank assigned as its manager a person whose knowledge in English were fluent, and so on, the official language of the European Central Bank is English, Luis Vuiton in France speaks English Antonio Merloni too etc.

In the years the English language has become a key tool in the world lidership gaining in books writing, world economy, daily use for varius purposes. It comes handy in trade transactions in all the globe, so the learning for the grown up adults is important for business managment in the world. But while English became an international language of technolgy and business it created a whole new generation of scholars that knew why they were learning it. Businesmen that wanted to sell their products, mechanics that needed it to read the handbooks of instructions, doctors that need it for the latest developments in their fileds and students, the course of whom involves texts boks, journals or different articles only in English language.

\section{Difficultes in Learning English}

It is common according to Broughton with any other subject of the curricula, teaching of English need to be done in accordance to the needs of students. The process of selection and breaking the body of knowledge or abilities in acquisition. Grading process is done for the teacher through the text, designers of syllabuses, teachng is structured and controlled by the foundamental theories.

But Alasgoff thinks that the fast distribution of the English language as an international language has raised some problems related to teaching it. The most important of all these has to do with the way how he challenges the key assumption of the conection between the language and identity and especially of what has to do with the "owning" of the language. In the majority of the cases is a tendency that learning the foreign language is treated simply as a distribution of the knwledge and values by those who know more (teachers) to those who know less (students). On other words teachers transmit to the students a kind of commodity called knowledge. This type of "learning" as a way of transition sees the knowledge as something static, public, written and formal.

Language allows that product of teaching can be treated as a measurable product. It considers teachers as "experts" and students as simply receptors and not responsible for any process of teaching. As a result of that students are characterized frequently passivity, create little experience and don't understand what goes on. A typical experience of learnng occurs frequently in lectures with "chalk and discussion" with e very little oportunity for students to participate, contribute or share point of viwes about topic or various types of learning. As it is understood hardly any learning occurs unders such circumstances. The process of learnng should be much more than that. Individuals do not live simply reacting in mechanical way and without taking into consideration 
the external influences. People make choices, choices how to interpret events and how to respond to the various situations, what purposes they have and how to achieve them better. According to Bandura these choices influence by the exercise of selfregulations (ability of people to influence their fate. People are not only reacting but they influence positively determining their directions in life. Ths point of view is fundamental for the theories of contructivism. Salmon argues that to be effective, educational plans must ease them in experimentation, teaching and understanding. Dewey believed that the way of learning happend

However the biggest difficulty of learning the freign language $n$ Albanian universitites is mainly the overfilled classes with a number of students beyond the capacities and especially with various knowledge in English which makes the job of teacher much more challenging hard and difficult to cope with.

\section{References}

Alasgoff L. (2001) "Identity and the EIL learner" on Alasgoff L "Principles and practices for teaching English as an international language" Routledge, fq 118

Alptekin, C. (2002). "Towards intercultural communicative competence in ELT". ELT Journal, 56(1), fq 57-64

Bandura A. (1978) "Percieved effectiveness: An explanatory mechanism of behavioral change. In G. Lindzey, C. S. Hall and R.F Thomspon "Psychology". New York Yorth

Broughton G. Brumfit Ch. Flavell R. Hill P. Pincas A. (2003) "Teaching English as a a foreign language" Routledge \& Kegan Paul Ltd Fq 109

Brown J.D. (2001) "ElL curriculum development" on Alasgoff L. et.al. (2012) "Principles and practices for teaching English as an international language" Rouledge, fq 150

Celce Murcia M. "Teaching English as a second or foreign language" Thomson learning, fq 10

Cortazzi, M., \& Jin, L. (1999). "Cultural mirrors: Materials and methods in the EFL classroom. In E. Hinkel (Ed.),

Culture in second language teaching" . Cambridge: Cambridge University Press, fq 197

Harding K. (2009) "English for specific purposes" Oxford University Press, fq 37

Harmer J (1998) "How to teach English" fq 127, Longman

Hutchinson T dhe Waters A "English for specific purposes " Cambridge University press

Joe Harkin (2001) "Teaching young adults", Routldge Falmer, , fq 35

Lin, B. (2002). "English as an international language: Discourse as an answer to what to teach and how to teach it. Conference proceedings of the $7^{\text {th }}$ annual Conference of Pan-Pacific Association of Applied Lingustics. fq. $1-16$

Llurda, E. (2004). "Non-native-speaker teachers and English as an international language". International Journal of Applied Linguistics, 14(3), 314-323.

McKay, S. L. (2003c). "EIL curriculum development". RELC Journal, 34(1), 31-47

Northrup. D (2013) "How English became the global language" fq 118, Palgrave Macmillan

Pennycook A. (2007) "Global English and transcultural flows" Routledge, fq 14

Poulson L. (1988) 'English courriculum in school' Wellington House, fq 101

Rogers C.R. (1969) "Freedom to learn" Merril Routledge \& Kegan Paul Ltd Fq 45

Salmon P. (1988, 1995) "Applying psichology in classroom"David Fulton Publishes

Sipas deklarates per shtyp te Komisionit Europian Bruksel, 20 shtator 2012 IP-12-990_EN

Warschauer, M. (2000). "The changing global economy and the future of English teaching" TESOL Quarterly, $34(3), 511$

Widdowson H.G. (1978) "Teaching language as communication" Oxford University Press, fq 178 